\title{
"The likelihood value of residual risk estimation in the management of enterprise risk"
}

\begin{tabular}{|c|c|}
\hline AUTHORS & Ronny Kountur (D) https://orcid.org/0000-0002-9923-2017 \\
\hline ARTICLE INFO & $\begin{array}{l}\text { Ronny Kountur (2018). The likelihood value of residual risk estimation in the } \\
\text { management of enterprise risk. Investment Management and Financial } \\
\text { Innovations, 15(3), 49-55. doi:10.21511/imfi.15(3).2018.04 }\end{array}$ \\
\hline DOI & http://dx.doi.org/10.21511/imfi.15(3).2018.04 \\
\hline RELEASED ON & Friday, 13 July 2018 \\
\hline RECEIVED ON & Tuesday, 24 April 2018 \\
\hline \multirow[t]{2}{*}{ ACCEPTED ON } & Tuesday, 26 June 2018 \\
\hline & $(\mathrm{cc}) \mathrm{EY}$ \\
\hline LICENSE & $\begin{array}{l}\text { This work is licensed under a Creative Commons Attribution } 4.0 \text { International } \\
\text { License }\end{array}$ \\
\hline JOURNAL & "Investment Management and Financial Innovations" \\
\hline ISSN PRINT & $1810-4967$ \\
\hline ISSN ONLINE & $1812-9358$ \\
\hline PUBLISHER & LLC "Consulting Publishing Company "Business Perspectives" \\
\hline FOUNDER & LLC "Consulting Publishing Company "Business Perspectives" \\
\hline
\end{tabular}

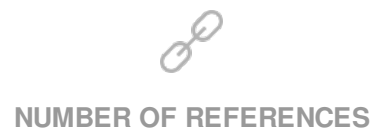

26

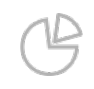

NUMBER OF FIGURES

2

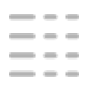

NUMBER OF TABLES

3

(C) The author(s) 2023. This publication is an open access article. 


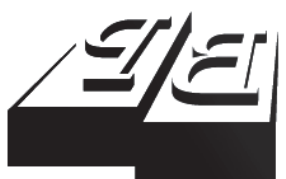

BUSINESS PERSPECTIVES

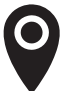

LLC "CPC "Business Perspectives" Hryhorii Skovoroda lane, 10, Sumy, 40022, Ukraine

www.businessperspectives.org

Received on: $24^{\text {th }}$ of April, 2018 Accepted on: $26^{\text {th }}$ of June, 2018

(c) Ronny Kountur, 2018

Ronny Kountur, Ph.D., PPM School Management, Indonesia.

\section{(c) (i)}

This is an Open Access article, distributed under the terms of the Creative Commons Attribution 4.0 International license, which permits unrestricted re-use, distribution, and reproduction in any medium, provided the original work is properly cited.
Ronny Kountur (Indonesia)

\section{THE LIKELIHOOD VALUE OF RESIDUAL RISK ESTIMATION IN THE MANAGEMENT OF ENTERPRISE RISK}

\begin{abstract}
A model for estimating the likelihood value of residual risk (Y) is introduced. The model consists of three independent variables: the likelihood value of risk before risk treatment (X1), the quality of risk treatment (X2), and the appropriateness of risk treatment (X3). An experimental research design with a multiple linear regression analysis was used in the estimation. All independent variables, the likelihood value of risk before treatment, the quality of risk treatment, and the appropriateness of risk treatment, can be significantly used to estimate the likelihood value of residual risk. Since no model of estimating residual risk of likelihood had been introduced yet, the findings of this study provide significant contribution to firms or organizations that need to assess the likelihood value of residual risks.
\end{abstract}

Keywords

JEL Classification

\section{assessment}

C13, C51, D81

\section{INTRODUCTION}

The practices of risk management in corporations had changed from mainly purchase insurance or hedging of interest rate and exchange rate exposure to integrated holistic risk management (Nocco \& Stulz, 2006; Anton, Lackes, \& Siepermann, 2015). This integrated holistic risk management is called Enterprise Risk Management (ERM). ERM seeks to link risk management with business strategy and goal setting (Arena, Arnaboldi, \& Azzone, 2010). ERM has become a new paradigm in risk mangement that integrates all of the risks faced by an enterprise (Bharathy \& McShane, 2014). Studies show that ERM has a significant positive impact on corporate value and performance (Gatzert \& Martin, 2015; Farrell \& Gallagher, 2015).

The Committee of Sponsoring Organizations (COSO), an organization dedicated to improve organizational performance and governance, introduced the COSO ERM framework in 2004 and updated it in 2016 (Everson \& Chesley, 2016). Those who did not embrace COSO's ERM framework made use of ISO 31000 Risk Mangement Standard that was introduced in 2009 (Gjerdrum \& Peter, 2011). The risk management process has several stages that involve risk identification, risk measurement, and risk control (Norrman \& Jansson, 2004; Gjerdrum \& Peter, 2011; Colombini, 2015; Kountur, 2016). Both the COSO ERM framework and the ISO 31000 Risk Management Standard have these three stages, but use different terms. COSO uses the terms Event Identification, Risk Assessment, and Risk Response, while ISO 31000 called them Risk Identification, Risk Analysis, and Risk Evaluation (Bowling \& Rieger, 2005; Aven, 2011; Gjerdrum \& 
Peter, 2011). Although the COSO ERM framework and the ISO 31000 Risk Management Standard have been introduced, organizations still struggle to effectively implement ERM (Taylor, Artman, \& Woelfer, 2012; Bharathy \& McShane, 2014). It fails to provide a workable standard for identifying ERM effectively (Williamson, 2007). There is no real consensus about the principal components of ERM. This leads to misidentification and measurements of risk that are inconsistent (Lundqvist, 2014).

\section{LITERATURE REVIEW}

Several methods of identifying risk have been introduced, such as the Business Process Model (Lambert, Jennings, \& Joshi, 2006), and the Business Process Analysis (Salmela, 2008). These models were then extended with step-by-step processes for identifying risk called Risk-Extended Process Model by Cope, Kuster, Etzweiler, Deleris, and Ray (2010). This model gives comprehensive information that was useful in identifying operational risks. The use of business processes in risk management has been the subject of active research in the past few years (Suriadi et al., 2014). Unfortunately, few studies have been done in measuring inherent and particularly residual risks. The most recent available literature on measuring residual risk was by Tolbert (2005).

The measurement of Frequency, Likelihood, and Severity was still based on judgments that were expressed in a scale from one to five as 'one' indicated the lowest and 'five' indicated the highest. This approach was the common traditional model of risk measurement in ERM that was still based on judgment, which is unable to measure risk objectively (Hakizabera \& Ohsato, 2010). Besides, this method does not separate the residual risk of likelihood and the residual risk of impact, which were important in risk mapping that was used in the integrated ERM system.

Measuring the impact value of residual risk was quite straightforward. For example, a car that has a value of USD 25 thousand faces a 30 percent likelihood of being stolen. To reduce the like- lihood of being stolen and to reduce the impact if it was stolen, the owner installed a car alarm and insured it for USD 20 thousand. The impact value of residual risk will be USD 5 thousand that was the remaining value after receiving payment from the insurance company. However, it will get complicated when measuring the likelihood value residual risk. What will be the residual risk of likelihood after installing car alarm? No model of predicting residual risk of likelihood after control that was used in ERM has been introduced yet, therefore, research needs to be conducted. Related literature to risk reduction indicated that perceived quality led to reduced perceived risk (Sweeney, Soutar, \& Johnson, 1999; Abdelrafe \& Hussin, 2011), while appropriateness in implementation reduces the risk (Mitchell, Bauknecht, \& Connor, 2006).

The main purpose of this study was to know whether the likelihood value of risk before risk treatment $\left(X_{1}\right)$, the quality of risk treatment $\left(X_{2}\right)$, and the appropriateness of risk treatment $\left(X_{3}\right)$ can be used to estimate the likelihood value of residual risk $(Y)$. The researcher hypothesized that these independent variables significantly estimate the likelihood value of residual risk. Further, to determine the coefficients $X_{1}, X_{2}$, and $X_{3}$ in order to develop the estimation model, this residual risk of likelihood value estimation model may be used by ERM practitioners in calculating the likelihood value of residual risk, which has been the gap so far. Residual risk of likelihood and residual risk of impact are important elements in ERM system, particularly as they are needed in developing a risk map and in determining the risk status.

$$
\text { Residual Risk Reduction }=\frac{\text { Baseline Risk Index }- \text { Subsequent Risk Index }}{\text { Baseline Risk Index }} \cdot 100 .
$$

Baseline Risk Index $=\sum($ Frequency $\cdot$ Likelihood $\cdot$ Severity $)$ of risks before controls; ${ }^{\text {and }}$

Subsequent Risk Index $=\sum($ Frequency $\cdot$ Likelihood $\cdot$ Severity $)$ of risk after controls. 


\section{METHOD}

This was an experimental research, where data were gathered through a questionnaire. The respondents of this study were undergraduate senior business administration (BA) students and masters of business administration (MBA) students. They were grouped in cluster by classes. The classes were taken randomly from the list of BA classes that were offered in that semester and from the list of MBA classes that were offered in that semester. This was an evening MBA class that was composed of working students, students who worked while studying. Most of them were in supervisory level that represent adult mature professional respondents. All students in the selected classes were taken for the study.

The respondents were given written risk management scenarios followed by seven questions. The answers to the questions were based on their responses to the scenarios.

The first question was about the likelihood of existing risk that was risk exposure before any risk treatment was given. In each of the scenarios, two different risk treatments were given. The purpose of providing more than one different risk treatment for each scenario was to increase the external validity of the study. Besides, the consistency of the answer can be measured.

The second question was about the 'first' residual risk of likelihood that was risk exposure after risk treatment was performed. The third question asked about the quality of the 'first' risk treatment. The respondent was given four choices and had to select one that was the most qualified in regard to the risk treatment provided. Each choice was given a value; the first choice had the highest value (four) and the last choice was the lowest value (one) (see Table 1).

The fourth question asked about the appropriateness of the 'first' treatment. There were four choices referring to the appropriateness of treatment from 'very appropriate' to 'inappropriate'. Each choices was given a value from four to one (see Table 2).
Table 1. The quality of risk treatment

\begin{tabular}{c|c}
$\begin{array}{c}\text { The value } \\
\text { of choices }\end{array}$ & \multicolumn{1}{c}{ Choice } \\
\hline 4 & $\begin{array}{l}\text { This is the best way of treating the likelihood of } \\
\text { occurrence and there are no other better ways } \\
\text { available }\end{array}$ \\
\hline 3 & $\begin{array}{l}\text { This is similar to other ways of treating the } \\
\text { likelihood of occurrence }\end{array}$ \\
\hline 2 & $\begin{array}{l}\text { This is not the best way, there are other better } \\
\text { ways of treating the likelihood of occurrence } \\
\text { This is the worst way of treating the likelihood } \\
\text { of occurrence compared with the other ways }\end{array}$ \\
\hline 1 &
\end{tabular}

Table 2. The appropriateness of risk treatment

\begin{tabular}{|c|c|}
\hline $\begin{array}{l}\text { The value } \\
\text { of choices }\end{array}$ & Choice \\
\hline 4 & $\begin{array}{l}\text { Very much appropriate: the treatment can } \\
\text { strongly reduce the likelihood of occurrence }\end{array}$ \\
\hline 3 & $\begin{array}{l}\text { Appropriate: the treatment can somehow } \\
\text { reduce the likelihood of occurrence }\end{array}$ \\
\hline 2 & $\begin{array}{l}\text { Less appropriate: the treatment seems to have } \\
\text { very little impact in reducing the likelihood of } \\
\text { occurrence }\end{array}$ \\
\hline 1 & $\begin{array}{l}\text { Inappropriate: the treatment seems unable to } \\
\text { reduce the likelihood of occurrence }\end{array}$ \\
\hline
\end{tabular}

The fifth question is about the 'second' residual risk of likelihood. When providing different ways of treating risk, how much likelihood will remain? The sixth question asked about the quality of the 'second' risk treatment. It was the same as the third question and had the same choices of answers as shown in Table 1 . The only difference was the risk treatment provided. And the seventh question - the last question - asked about the appropriateness of the 'second' risk treatment. This was the same as the fourth question and had the same choices as shown in Table 2.

Three questionnaires were designed. Each questionnaire had two different risk management scenarios with the same questions. The purpose of having more than one scenario was to reduce the treatment bias and increase the external validity of the study. Each respondent exposed to one scenario with two different risk treatments. In total, this study exposed three scenarios with six different risk treatments.

The first scenario was about the risk of sound system failure at a music show. This questionnaire was given to the first cluster of 19 BA students. Four students did not fill out the questionnaire completely and were removed from the study, which left 15 students from the first cluster. 
The second scenario was about the risk of electrical appliances being destroyed due to a power outage. This second questionnaire was given to the second cluster of 23 BA students. Only one student did not answer the questionnaire completely and was removed from the study, which left 22 respondents.

The third scenario was about the risk of a car accident to a driver without a driving license. This third questionnaire was given to the third cluster of 20 MBA students. There was one student who did not return the questionnaire, which left 19 respondents.

There were 56 complete questionnaires collected in total. Since each respondent was required to answer two different scenarios, in total, there were 108 scenarios being analyzed. There was 68.32 percent consistency in answering the questionnaire as measured by the correlation between residual risk of likelihood of the first and second controls.

Multiple linear regression analysis was used in analyzing the data with a significance level of 5 percent or 95 percent level of confidence. The assumptions of normality, linearity, collinearity, and scedasticity were tested. Since the sample size was relatively small, regression assumptions must be strictly followed. The sample size would not be an issue if the regression assumptions were fulfilled.

\section{RESULTS}

In the assessment of risk, can inherent risk of likelihood, quality of risk control, and appropriateness of risk treatment be used to estimate the residual risk of likelihood? A multiple linear regression analysis was calculated to estimate the residual risk of likelihood of risk after being treated based on the existing risk of likelihood, the quality of risk treatment, and the appropriateness of risk treatment. The use of multiple linear regression required that the data were normally distributed, linearly related, no collinearity, and no heteroscedasticity. The data were normally distributed, since the residuals plots are along the line of normal P-P plots graph as shown in Figure 1.

The assumption of normality, linearity, and scedasticity can also be examined through the use of scatterplot between regression standardized predictive value and regression standardized residual. The data were again confirmed to be normally distributed, since the regression standardized residual has a horizontal-line relationship with standardized predicted scores (Tabachnick \& Fidell, 2013), as shown in Figure 2. Linearity of relationship was also assumed, since the overall shape of the scatterplot tended towards rectangular (see Figure 2). Its shape was curved when nonlinearity was present. No heteroscedasticity was also found, since the distribution of regression standardized

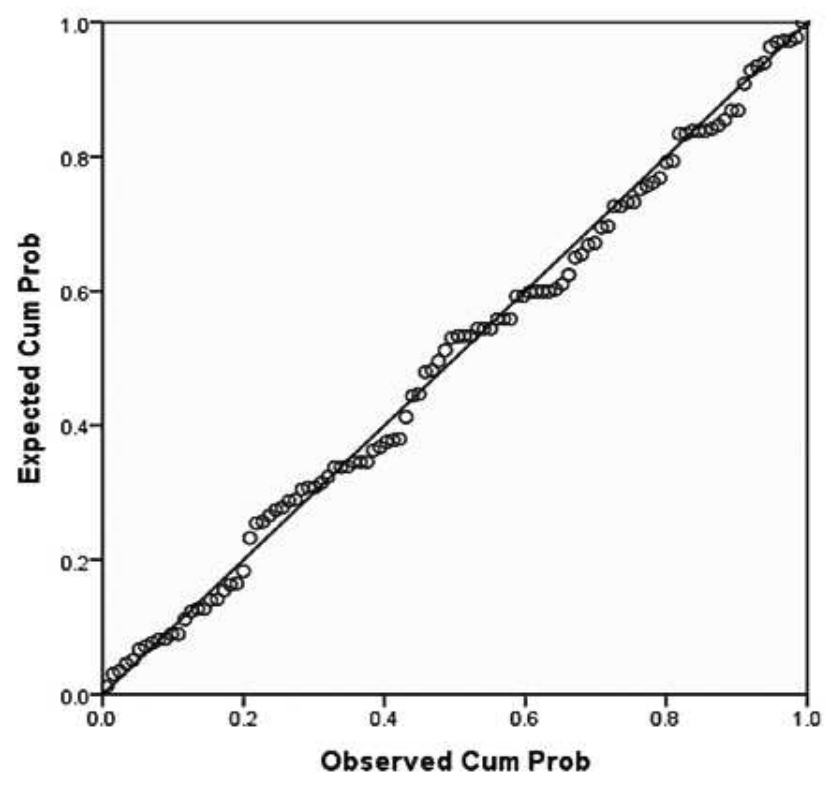

Figure 1. Normal P-P plot: residual probability 


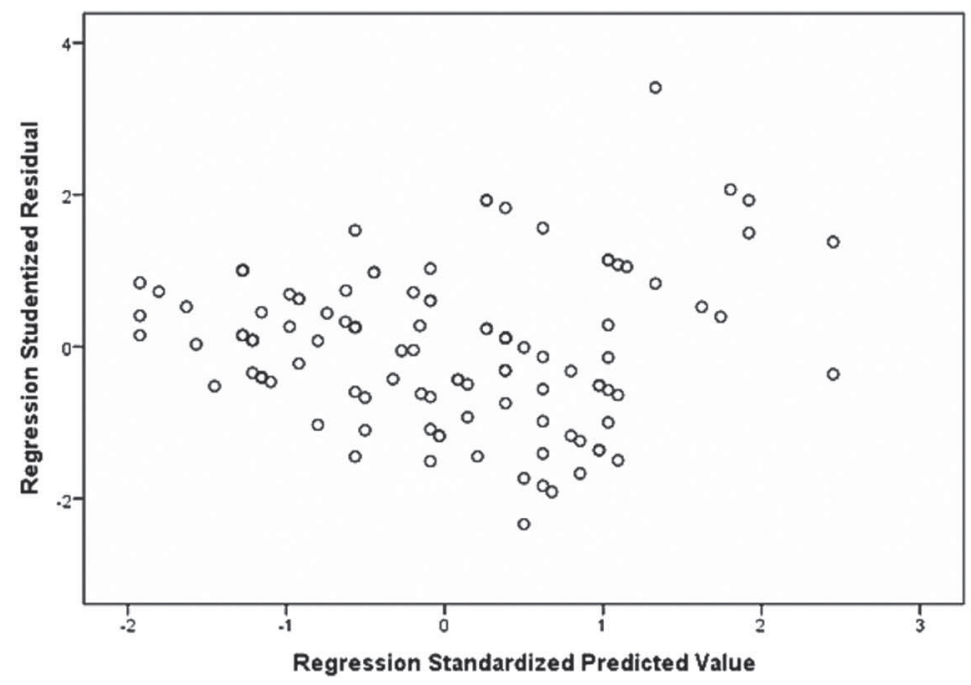

Figure 2. Scatterplot dependent variable: residual probability

residual and standardized predictive scores of independent variables was random (Tabachnick \& Fidell, 2013) as shown in Figure 2. Further, no collinearity existed among independent variables, since collinearity statistics of Tolerance and Variance Inflation Factor (VIF) were close to one (Tabachnick \& Fidell, 2013) (see Table 3).

Table 3. Collinearity statistics

\begin{tabular}{l|c|c}
\hline \multirow{2}{*}{ Model } & \multicolumn{2}{c}{ Collinearity statistics } \\
\cline { 2 - 3 } & Tolerance & VIF \\
\hline (Constant) & - & - \\
\hdashline Inherent likelihood & .975 & 1.026 \\
Quality of risk control & .762 & 1.313 \\
\hline Effectiveness of risk control & .774 & 1.293 \\
\hline
\end{tabular}

A significant regression equation was found $(F(3,104)=38.26, p<0.05)$ with $R^{2}$ of 52 percent. In this predictive model, fifty two percent variance in residual risk of likelihood can be explained by risk of likelihood before treatment, quality of risk treatment, and effectiveness of risk treatment. The predictive model of residual risk of likelihood estimation was as follows:

$$
Y=42+0.44 X_{1}-5.84 X_{2}-7.98 X_{3} \text {, }
$$

where $Y$ - residual risk of likelihood, $X_{1}$ - risk of likelihood before control, $X_{2}$ - quality of risk control, $X_{3}$ - effectiveness of risk control.
The likelihood of residual risk and the risk before treatment were expressed in percentages. Quality of risk control was expressed in scores from 1 to 4 , where one indicated the worst ways of handling the likelihood of occurrence as compared to other ways, while four indicated the best way of handing the likelihood of occurrence and there was no other better ways available (see Table 1). Effectiveness of risk control was expressed in scores from 1 to 4 too. 'One' indicated ineffective that the control seemed unable to reduce the likelihood of occurrence, while 'four' indicated very effective that the control can strongly reduce the probability of occurrence (see Table 2). The likelihood of risk before control $(p=.00)$, quality of risk control $(p=.00)$, and effectiveness of risk control $(p=.00)$, all as predictor variables, were significantly estimators of residual risk of likelihood.

\section{DISCUSSION}

Risk that existed in any event may be reduced by implementing some risk treatments. There were two elements of risks, likelihood and impact. Some risk treatments were intended to reduce the likelihood of loss event and some risk treatments were intended to reduce the impact or the loss of that event. The likelihood and the impact before risk treatment was known as the existing risk, while the likelihood and impact after the risk treatment was known as the residual risk. Measuring residu- 
al impact was quite straightforward, but measuring residual risk of likelihood was a challenge, as Taylor, Artman, and Woelfer (2012), and Bharathy, and McShane (2014) have found that organizations still struggle to effectively implement ERM.

The researcher found that quality of risk treatment was a significant predictor of the likelihood value of residual risk, which was consistent with studies by Sheeney, Soutar, and Johnson (1999), and Abdelrafe and Connor (2006) who found that perceived quality led to reduced perceived risk. The study also found that appropriate use of equipment reduced the risk of loss (Mitchell, Bauknecht, \& Connor, 2006). That study supported the findings of this study that the appropriateness of implementation of risk treatment reduces the likelihood of risk. Both the quality of risk treatment and the appropriateness of risk treatment can be used as predictors to the likelihood value of residual risk. This was a way of knowing how much likelihood remained after risk had been treated. This has been the gap in the implementation of risk assessment in ERM so far (Williamson, 2007; Taylor, Artman, \& Woelfer, 2012; Bharathy \& McShane, 2014; Lundqvist, 2014). The findings of this study filled this gap.

A predictive model of estimating the residual risk of likelihood of risk event $(Y)$ was introduced in this study. The likelihood of risk before treatment $\left(X_{1}\right)$, quality of risk treatment $\left(X_{2}\right)$, and appropriateness of risk treatment $\left(X_{3}\right)$ were the predictors of likelihood value of residual risk. A previous study by Tolbert (2005) had introduced a model of measuring residual risk; however, it differed in two aspects. First, no differences were made between residual risk of likelihood and residual impact in that study, second, it did not consider the quality and appropriateness of risk treatment.

\section{CONCLUSION}

A model of predicting residual risk of likelihood value in the management of enterprise risk is very much needed, since it is used in developing risk map and no such model has been introduced yet. The predictive model in estimating likelihood value as residual risk introduced in this study has significant implications to those companies that implement ERM, and to risk management professionals.

This study was not without limitations. The sample size of 108 was still considered medium which suggests further study with a larger sample size. Though it was acceptable, the 52 percent $R^{2}$ was unsatisfactory. That might be due to the few predictor variables that were included in this predictive model. More variables may be added in the model as predictors for further study to improve the $R^{2}$.

\section{REFERENCES}

1. Abdelrafe, E., \& Hussin, B. (2011). Estimating quality-affecting risks in software projects. The International Management Review, 7(2), 66-74. Retrieved from https://www.questia.com/ library/journal/1P3-2520623821/ estimating-quality-affecting-risksin-software-projects

2. Anton, T., Lackes, R., \& Siepermann, M. (2015). Integration of risk aspects into business process modeling. Paper presented at $4^{\text {th }}$ International Conference on Enterprise Resource Planning, ERP Future 2015, 16-17 November.

3. Arena, M., \& Azzone, G. (2010). The organizational dynamics of enterprise risk management. Accounting, Organizations and Society, 35(7), 659-675.

4. Aven, T. (2011). On the new ISO guide on risk management terminology. Reliability Engineering \& System Safety, 96(7), 719-726.

5. Bharathy, G. K., \& McShane, M. K. (2014). Applying a system model to enterprise risk management. Engineering Management Journal, 26(4), 38-46. https://doi.org/10.10 80/10429247.2014.11432027

6. Bowling, D. M., \& Rieger, L. (2005). Success factors for implementing enterprise risk management: building on the
COSO framework for enterprise risk management to reduce overall risk. Bank Accounting \& Finance, Apr-May, 21.

7. Colombini, F. (2015). Risk, regulation, supervision and crises in the European Banking Union. Law and Economics Yearly Review, 4(2), 236-273.

8. Cope, E. W., Kuster, J. M., Etzweiler, D., Deleris L. A., \& Ray, B. (2010). Incorporating risk into business process models. IBM Journal of Research and Development, 54(3).

9. Everson, M. E. A., \& Chesley, D. L. (June 2016). Aligning risk with 
strategy and performance: Executive summary. Retrieved from www. coso.org/Documents/COSO-ERMExec-Summary-draft-Post-Exposure-version.pdf

10. Farrell, M., \& Gallagher, R. (2015). The valuation implications of enterprise risk management maturity Journal of Risk \& Insurance, 82(3), 625-657. https://doi.org/10.1111/ jori. 12035

11. Gatzert, N., \& Martin, M. (2015). Determinants and value of enterprise risk management: Empirical evidence from the literature. Risk Management and Insurance Review, 18(1), 29-53. https://doi. org/10.1111/rmir.12028

12. Gjerdrum, D., \& Peter, M. (2011). The New International Standard on the Practice of Risk Management A Comparison of ISO 31000:2009 and the COSO ERM Framework. Society of Actuaries, 12, 8-12.

13. Hakizabera, A. U., \& Ohsato, A. (2010). Early risk assessment in software development life cycle using software metrics. Proceedings of the International Conference on Information Management \& Evaluation, 122-128.

14. Kountur, R. (2016). Asesmen Risiko Terintegrasi: Quantitative Approach. Jakarta: PT RAP Indonesia.
15. Lambert, J. H., Jennings, R. K., \& Joshi, N. N. (2006). Integration of risk identification with business process model. System Engineering, 9(3), 187-198.

16. Lundqvist, S. A. (2014). An exploratory study of enterprise risk Management: Pillars of ERM. Journal of Accounting, Auditing \& Finance, 29(3), 393-429.

17. Mitchell, C., Bauknecht, D., \& Connor, P. M. (2006). Effectiveness through risk reduction: A comparison of the renewable obligation in England and Wales and the feed-in system in Germany. Energy Policy, 34(3), 297-305.

18. Nocco, B. W., \& Stulz, R. M. (2006). Enterprise risk management: Theory and practice. Journal of Applied Corporate Finance, 18(4), 8-20.

19. Norrman, A., \& Jansson, U. (2004). Ericsson's proactive supply chain risk management approach after a serious sub-supplier accident. International Journal of Physical Distribution \& Logistics Management, 34(5), 434-456.

20. Salmela, H. H. S. (2008). Analyzing business losses caused by information systems risk: a business process analysis approach. Journal of Information Technology, 23(3), 185-202.

21. Suriadi, S. et al. (2014). Current research in risk-aware business process management-overview, comparison, and gap analysis. Communication of the Association for Information Systems, 34(1), 933-984.

22. Sweeney, J. C., Soutar, G. N., \& Johnson, L. W. (1999). The role of perceived risk in the quality-value relationship: A study in a retail environment. Journal of Retailing, 75(1), 77-105.

23. Tabachnick, B. G., \& Fidel, L. S. (2013). Using Multivariate Statistics (6th ed.). Boston: Pearson.

24. Taylor, A., Artman, E., \& Woelfer, J. P. (2012). Information technolgy project risk management: bridging the gap between research and practice. Journal of Information Technology, 27(1), 17-34.

25. Tolbert, G. D. (2005). Residual risk reduction: Systematically deciding what is "safe". Professional Safety. Retrieved from www.asse.org

26. Williamson, D. (2007). The COSO ERM framework: a critique from system theory of management control. International Journal of Risk Assessment and Management, 7(8), 1089-1119. 